\title{
Original Article \\ Sequence analysis of 18SrDNA gene from sagoplast degrading fungi
}

\author{
Tri Gunaedi and Arsyam Mawardi* \\ Department of Biology, Faculty of Mathematics and Natural Sciences, Cenderawasih University, Jayapura, Papua
}

\begin{abstract}
The bioplastic can be made from sago flour and known as sagoplast. It was widely known that for making bioplastic, the addition of acetic acid and glycerol are needed. Products that are air-dried are easy to grow fungi within a few weeks. This makes the basis for researchers to undestand more about the character and identity of the sagoplast degrading fungi. Characterization and identification were carried out by observed morphology and analyzing the 18SrDNA gene sequence of fungal isolates that had grown on the sagoplast. Fungal isolates morphology showed yellowish-orange color with white thread-like mycelia and a blackish brown mace with white thread-shaped mycelia. These characters of fungal morphology that similar with Aspergillus. The gene sequences of the fungal isolates were aligned with reference gene sequences of the fungi obtained from the Gen Bank of the National Center for Biotechnology Information (NCBI). Sequence data analysis was performed by using the Clustal X program to determine the kinship and taxonomy of the fungal isolates that able to degrade sagoplast. The result showed that two fungal isolates, DFSP.J1 and DFSP.J4, were found and demonstrated their ability for degrading sagoplast. Isolate DFSP.J1 is related to Aspergillus flavus strain PSU2 LC127086.1, while isolate DFSP.J4 is related to Aspergillus niger IFO4033 D63697.1.
\end{abstract}

Keywords: Degradation, fungi, sagoplast, sequence gene.

Received:21 December 2020 Revised: 05 April 2021 Accepted: 05 April 2021

\section{Introduction}

Sago flour can be used as a substrate in the formation of bioplastic by fermentation or using acetic acid and glycerol as a plasticizer. The resulting bioplastic is called a sagoplast. The use of sago flour as a bioplastic material is expected to open opportunities for the development of various industries made from environmentally friendly sago bioplastics in Indonesia and in Papua. The use of bioplastics is being campaigned to replace hydrocarbon plastics which have a relatively longer degradation time than bioplastics. This is due to insolubility of synthetic plastics in water which causes the slow degradation process by microorganisms (Alshehrei, 2017).

Polymers from bioplastic are relatively easier to be degraded by various types of microorganisms, including fungi, bacteria and algae (Reddy et al., 2008). The microorganisms that can degrade bioplastics in soil, including those from the bacterial group, namely Pseudomonas sp., Streptococcus sp., Staphylococcus sp., Bacillus sp., and Moraxella sp. (Maran et al., 2014) Meanwhile, the fungi are Aspergillus niger, A. versicolor, Cladosporium sp, Fusarium sp, Tricoderma sp and Verticillium sp (Szumigaj et al., 2008). The ability of microorganisms to degrade bioplastics is determined by the components and size of the bioplastic (Sihaloho, 2011). In addition to the size of bioplastics, glycerol content determines the speed of degradation by soil microorganisms (Wahyuningtyas and Suryanto, 2017). In addition, it is also due to the habit of these

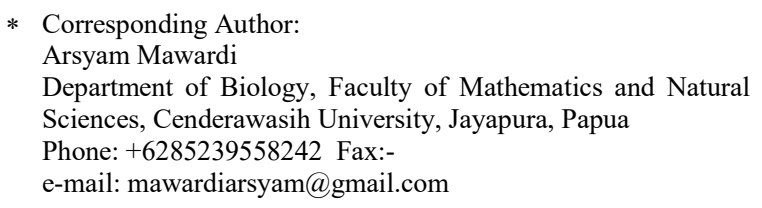

microorganisms to find substrates in the form of bioplastics in the soil environment (Adhikari et al., 2016).

The initial research of making bioplastics made from sago flour with acetic acid as a catalyst and glycerol as a plasticizer was done. After two weeks of sagoplast stored in the open space, it was found that the sagoplast had been overgrown with fungi. The morphological characteristics are shaped like strands of clear, smooth, non-slippery white thread that sticks to the bioplastic surface. Based on the character of the spectrum of the starch content substrate, the fungus has the potential to have a broad spectrum and can possibly be applied to degrade bioplastics with substrates from other renewable materials. The potential of the fungus needs to be developed by providing habituation treatment from the lowest to the highest concentration and size of the bioplastic to obtain optimal degradation speed and time with a certain fungal inoculum concentration. Before this stage, it is necessary to detect the taxon position of the fungus early so that it is clearer the metabolic characteristics and other characters that can be used to treat the fungus so that it is easier to degrade bioplastics.

Isolate of microorganisms from the type of bioplastic degrading fungi can be determined the position of the taxon by analyzing the 18 SrDNA gene sequence (Mishra et al., 2013). The 18 SrDNA gene is known as a marker gene for eukaryotic organisms in which the fungus is included (Wu et al., 2003). The results of gene sequence analysis resulted in phylogenetic trees to see the relationship between isolates of bioplastic-degrading fungi with reference to fungal isolates that had been identified and classified by previous researchers stored in the genbank database at National Center Biotechnology Information United States of America (NCBI-USA). 


\section{Methods}

Making sagoplast

The sago flour used was traditionally processed and dried sago flour, then blended, filtered and packaged. Making sagoplast was done by adding sterile aquadest to sago flour in a stainless steel pan with a temperature of $70{ }^{\circ} \mathrm{C}$ with a composition of $1 \% \mathrm{v} / \mathrm{v}$ acetic acid, $1 \% \mathrm{v} / \mathrm{v}$ glycerol and $15 \% \mathrm{w} / \mathrm{v}$ sago flour. The heating was carried out while stirring until the sago flour was dissolved and the suspense looked clear, then it was printed in a $25 \mathrm{~cm}^{2}$ plastic mold. The bioplastic that has been formed is put in an oven at $45^{\circ} \mathrm{C}$ and determined.

\section{Isolation and selection of sagoplast degrading fungi.}

The isolation of sagoplast-degrading microorganisms was carried out by placing the sagoplast with a size of 25 $\mathrm{cm}^{2}$ on an open plastic tray and placed on a table for 14 days. After the growth of microorganisms appears, the sagoplast sheet that has been overgrown with microorganisms is cut to a size of $2 \mathrm{~cm}^{2}$ and put into an erlenmeyer containing sterile aquadest, then isolation is carried out by inoculating it into Potato Dextrose Agar (PDA Oxoid) medium to produce spores. The spores from the obtained isolate fungi were then grown in Potato Dextrose Broth medium and shaken at $100 \mathrm{rpm}$ for 7 days. Fungal spore suspensions of $0.1,0.2,0.3,0.4$, $0.5 \mathrm{ml}$ were tested for their degradability by growing them in a petridish containing 1 gram of sagoplast each with a size of $0.5 \mathrm{~cm}^{2}$, for 14 days, at room temperature. The degradability of the function is determined by the formula: $D P=((W i-W t) / W i) \times 100 \%$

$\mathrm{DP}=$ degdrability percentage,

$\mathrm{Wt}=$ weight in time and $\mathrm{Wi}=$ initial weight.

\section{Cultures and genomic DNA isolation.}

Genomic DNA was isolated from pure culture of each fungal strain and genomic DNA extraction using Quick-DNA TM Fungal / Bacterial Miniprep Kit (D6005). Amplification PCR using MyTaq HS Red Mix (Bioline). Total PCR Master MIX components were 1 x $25 \mu$, consisting of $10.5 \mu \mathrm{lddH} 2 \mathrm{O}, 12.5 \mu \mathrm{l}$ My Taq Red Mix, 2x., $20 \mu \mathrm{mol} / \mu \mathrm{l} 18 \mathrm{SF}$ Primer (Sequence 18S_E18F GATCCMGGTTGATYCTGCC) of $0.5 \mu 1,20 \mu \mathrm{mol} / \mu 1$ 18SR 18S_E1772R ACGGYTAC CTTGTTACGACTT) as much as $0.5 \mu \mathrm{l}$. and $1 \mu \mathrm{l}$ of template DNA. PCR conditions were preceded by Initial Denaturation at $95{ }^{\circ} \mathrm{C}$ for $1 \mathrm{~min}$ with a cycle of 1 time. The denaturation stage at $95{ }^{\circ} \mathrm{C}$ for $15 \mathrm{~min}$, the annealing stage at $52{ }^{\circ} \mathrm{C}$ for $15 \mathrm{~min}$ and the extension stage at $72^{\circ} \mathrm{C}$ for $45 \mathrm{~min}$ with 35 cycles each. Stages of hold at $4{ }^{\circ} \mathrm{C} 1$ time. PCR products purification with Zymoclean ${ }^{\circledR}$ Gel DNA Recovery Kit (Zymo Research). Aliquots of 1uL PCR products were analyzed in $0.8 \%(\mathrm{w} / \mathrm{v})$ TBE agarose (Sigma) gel. Electrophoresis products were seen with UV-Vis after staining with ethidium bromide $(0.5 \mathrm{mg} / \mathrm{L})$. The pure PCR product was then sequenced using the ABI3100 sequencer (Applied Biosystems).

\section{Sequence data analysis}

For identification of the strains, the obtained nucleotide sequences were compared to those already stored in the National Center for Biotechnology and Information (NCBI) sequence database, using a research tool, BLAST. The distance matrix for all pairwise sequence combinations was analyzed with the NeighborJoining (NJ) method (Saitou and Nei, 1987), of phylogenetic tree construction with 1,000 bootstrap replicates by using Clustal $\mathrm{X}$ version $1.62 \mathrm{~b}$ software.

\section{Results}

The results of making Sagoplast using sago starch, acetic acid and glycerol were the best for use in this study with the composition: $15 \% \mathrm{w} / \mathrm{v}$ sago starch, $1 \%$ $\mathrm{v} / \mathrm{v}$ acetic acid and $1 \% \mathrm{v} / \mathrm{v}$ glycerol. The sagoplast obtained is, as shown in Figure 1, has a thickness of 0.2 $\mathrm{cm}$ and a moisture content of $15.25 \%$. Sagoplast is transparent, plasticity and looks a little stiff and is not easy to tear by hand.

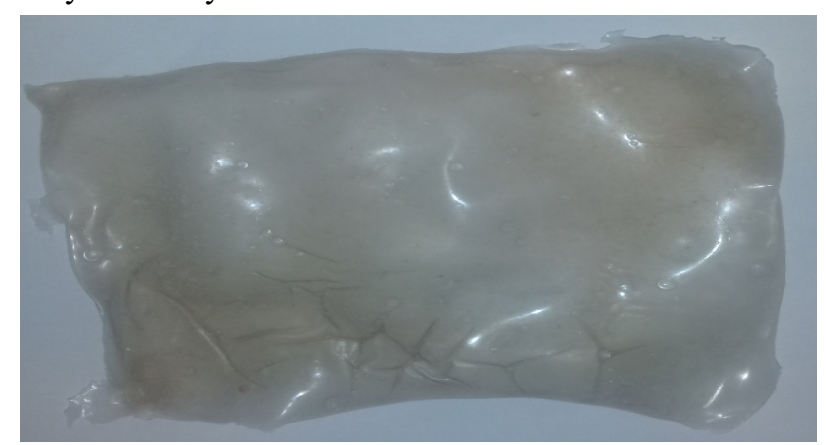

Figure 1. Sagoplast dry sheet

The cell morphology characters of fungal isolates were identified, isolate DFSP.J1 has a mace-shaped conidiophore character with a yellowish-orange color with white thread-like mycelia. While the DFSP.J4 isolate has the character of a conidiophore in the form of a club in the shape of a blackish brown mace with white thread-shaped mycelia, as in Figure 2.

After testing the degradation power of the fungi isolates against the sagoplast by inoculating the fungal isolate cultures with different concentrations into a petri dish containing 1 gram of sagoplast with a size of 0.5 $\mathrm{cm}^{2}$. The results of observations after being incubated for 1 week and observed every day for one week and weekly intervals for 3 weeks. Obtained that DFSP.J1 isolate was able to degrade sagoplast by $56.52 \%$ at an inoculum concentration of $0.4 \mathrm{ml}$ and tended to continue to degrade in the third week to the fifth week of observation. While the DFSP.J4 isolate was able to degrade sagoplast by $55.90 \%$ at an inoculum concentration of $0.3 \mathrm{ml}$ but had a tendency to degrade constantly on the third to fifth week of observation. This can be seen in Figure 3, and Figure 4. 


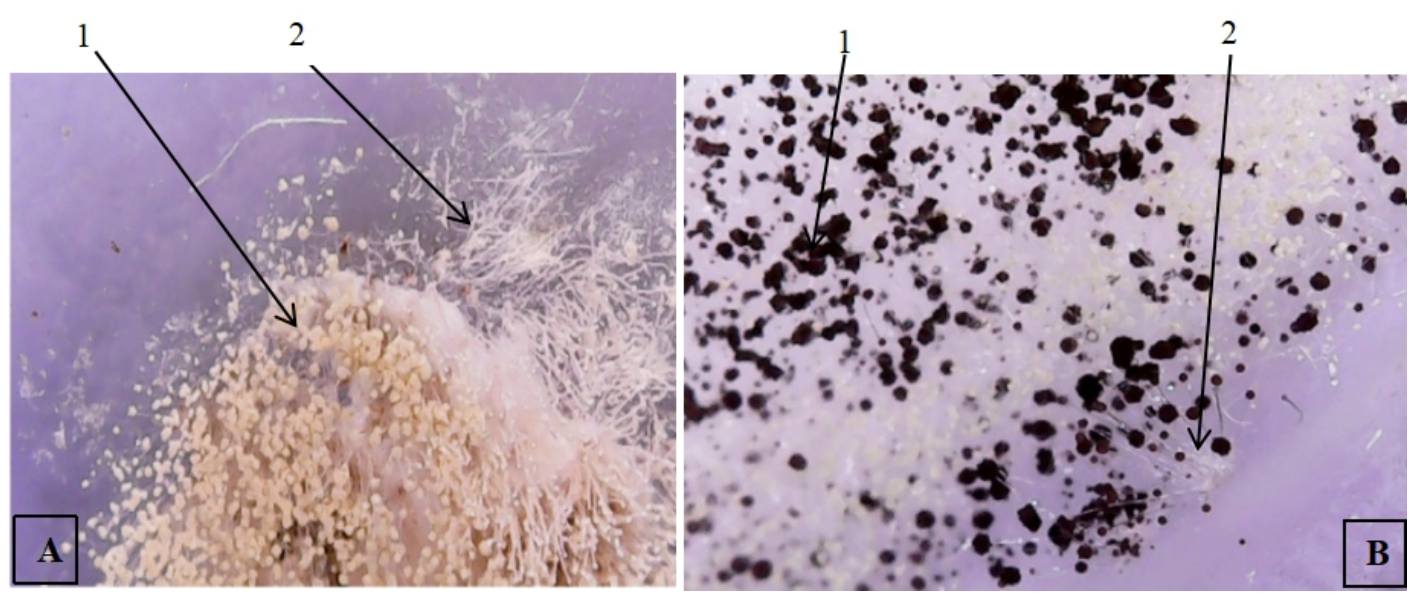

Figure 2. Isolate DFSP.J1 (A) and Isolate DFSP.J4 (B), photo taken using a digital microscope with a resolution of 640 x 480 Notes :( 1) conidiaphore and (2) mycelia
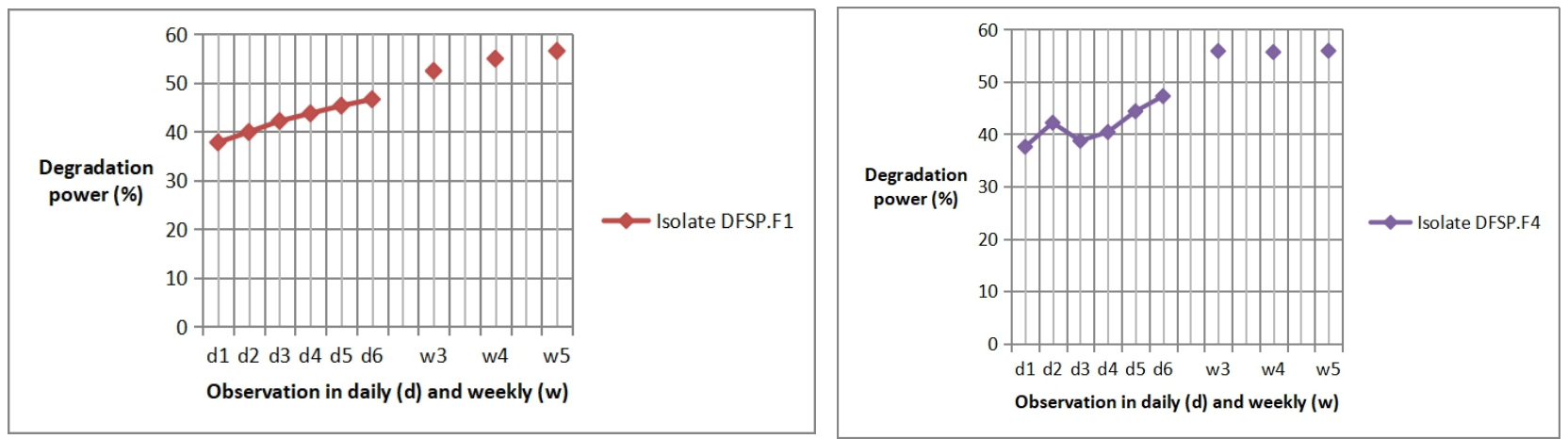

Figure 3. Degdaration power (\%) of DFSP.J1 and DFSP.J4 isolates to the sagoplast for five weeks of observation
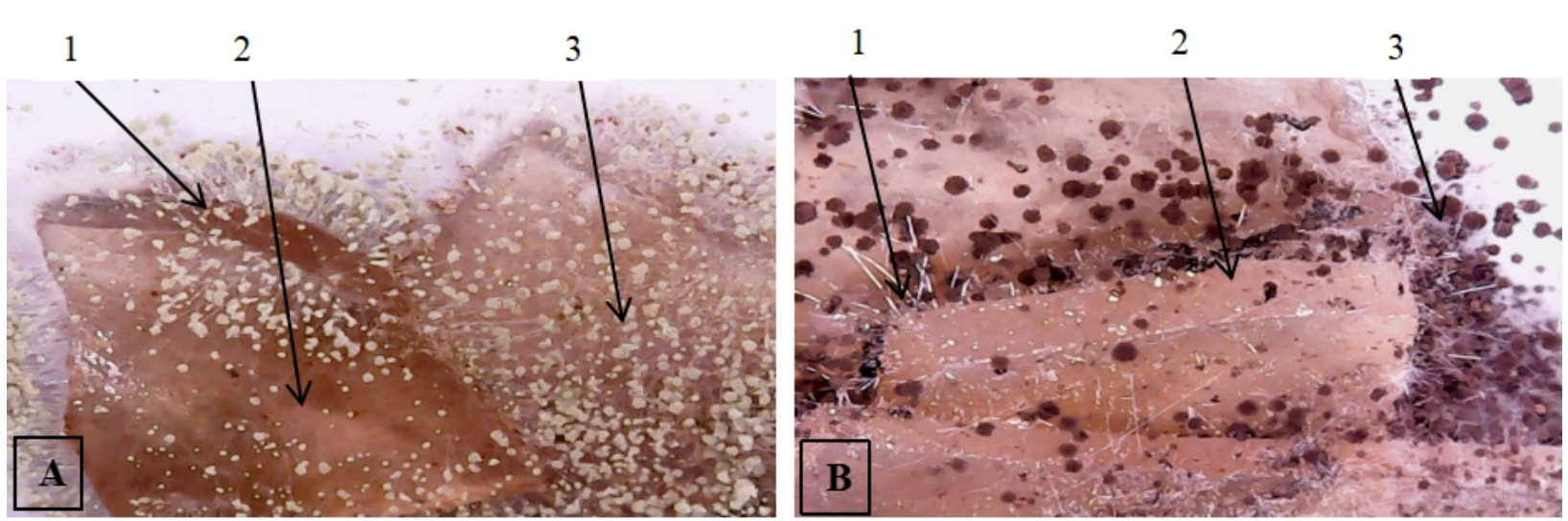

Figure 4. Isolate DFSP.J1 (A) and Isolate DFSP.J4 (B) are degrading sagoplast, photos were taken using a digital microscope with a resolution of 640x480. Notes: (1) mycelia, (2) sagoplast and (3) conidiaphore

The results of the 18SrDNA gene sequence analysis of the sagoplast-degrading fungi showed that the DFSP.J1 isolate was a member of the species and closely related to the reference strain A. flavus PSU2 LC127086.1 with percentage identity $100 \%$ with the number of different nucleotides as much as $0 \backslash 1587$. In other hand DFSP.J4 isolate which is a member of the species and is closely related to the reference strain $A$. niger IFO4033 D63697.1 with percentage identity value $99.94 \%$, with the number of different nucleotides $1 \backslash 1703$. Showed in table 1 and 2. Regarding a phylogenetic tree which illustrates the relationship between the two isolates of the degrading fungi with the reference strain of the genus Aspergillus, showed in Figure 5. 
Table 1.The similarity value of $18 \mathrm{~S}$ rRNA (\%) and the number of different nucleotides of the sagoplast-degrading fungal isolate DFSP.J1 isolate with several fungal strains of the genus Aspergillus.

\begin{tabular}{|c|c|c|c|c|c|c|c|c|c|c|}
\hline $\begin{array}{l}\text { STRAINS } \\
\text { CODE }\end{array}$ & 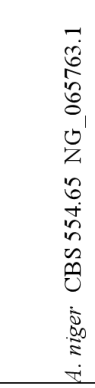 & 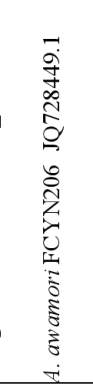 & 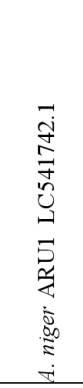 & 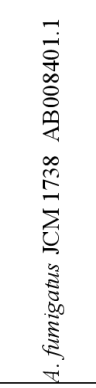 & 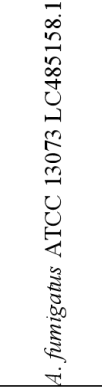 & 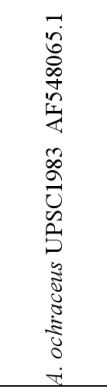 & 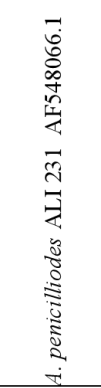 & 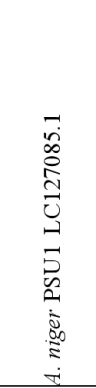 & 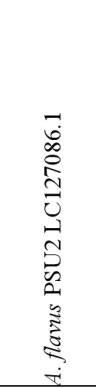 & 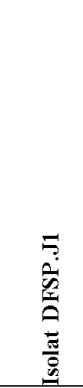 \\
\hline $\begin{array}{l}\text { A.niger } \\
\text { CBS 554.65 } \\
\text { NG_065763.1 }\end{array}$ & --- & $0 / 1332$ & $6 / 1668$ & $44 / 1724$ & $44 / 1724$ & $28 / 1690$ & $37 / 1690$ & $17 / 1577$ & $9 / 1587$ & $27 / 1697$ \\
\hline $\begin{array}{l}\text { A.awamori } \\
\text { FCYN206 } \\
\text { JQ728449.1 }\end{array}$ & 100 & --- & $0 / 1332$ & $12 / 1333$ & $12 / 1333$ & $10 / 1320$ & $14 / 1320$ & $16 / 1303$ & $8 / 1303$ & $12 / 1333$ \\
\hline $\begin{array}{l}\text { A.niger ARU1 } \\
\text { LC541742.1 }\end{array}$ & 99.64 & 100 & -- & $17 / 1669$ & $17 / 1669$ & $12 / 1639$ & $20 / 1639$ & $17 / 1577$ & $9 / 1587$ & $17 / 1663$ \\
\hline $\begin{array}{l}\text { A. fumigatus } \\
\text { JCM } 1738 \\
\text { AB008401.1 }\end{array}$ & 97.45 & 99.1 & 98.98 & -- & $0 / 1733$ & $10 / 1692$ & $20 / 1692$ & $18 / 1577$ & $3 / 1587$ & $13 / 1699$ \\
\hline $\begin{array}{l}\text { A. fumigatus } \\
\text { ATCC } 13073 \\
\text { LC485158.1 }\end{array}$ & 97.45 & 99.1 & 98.98 & 100 & -- & $10 / 1692$ & 20/1692 & $18 / 1577$ & $3 / 1587$ & $13 / 1690$ \\
\hline $\begin{array}{l}\text { A. ochraceus } \\
\text { UPSC1983 } \\
\text { AF548065.1 }\end{array}$ & 98.34 & 99.24 & 99.27 & 99.41 & 99.41 & -- & $23 / 1692$ & $21 / 1577$ & $11 / 1587$ & $18 / 1674$ \\
\hline $\begin{array}{l}\text { A. penicilliodes } \\
\text { ALI } 231 \\
\text { AF548066.1 }\end{array}$ & 97.81 & 98.94 & 98.78 & 98.82 & 98.82 & 98.64 & -- & $28 / 1577$ & $15 / 1587$ & $24 / 1674$ \\
\hline $\begin{array}{l}\text { A. niger PSU1 } \\
\text { LC127085.1 }\end{array}$ & 98.92 & 98.77 & 98.92 & 98.86 & 98.86 & 98.67 & 98.22 & -- & $21 / 1576$ & $21 / 1577$ \\
\hline $\begin{array}{l}\text { A. flavus } \text { PSU2 } \\
\text { LC127086.1 }\end{array}$ & 99.43 & 99.39 & 99.43 & 99.81 & 99.81 & 99.31 & 99.05 & 98.67 & -- & $0 / 1587$ \\
\hline $\begin{array}{l}\text { Isolate } \\
\text { DFSP.J1 }\end{array}$ & 98.41 & 99.1 & 98.98 & 99.23 & 99.23 & 98.92 & 98.57 & 98.67 & 100 & --- \\
\hline
\end{tabular}

Table 2.The similarity value of $18 \mathrm{~S}$ rRNA (\%) and the number of different nucleotides of the sagoplast-degrading fungal isolate DFSP.J4 isolate with several fungal strains of the genus Aspergillus.

\begin{tabular}{|c|c|c|c|c|c|c|c|c|c|}
\hline $\begin{array}{c}\text { STRAINS } \\
\text { CODE }\end{array}$ & 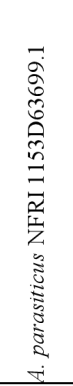 & 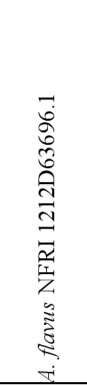 & 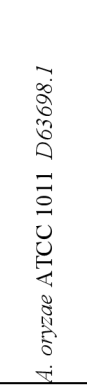 & 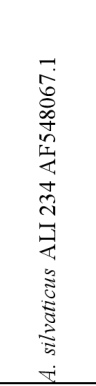 & 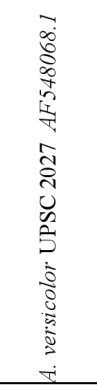 & 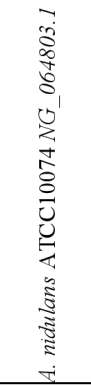 & 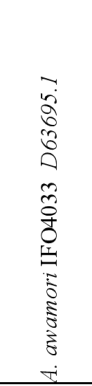 & 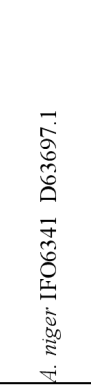 & 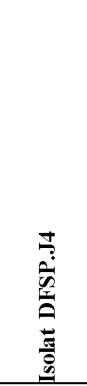 \\
\hline $\begin{array}{l}\text { A. parasiticus } \\
\text { NFRI } 1153 \\
\text { D63699.1 }\end{array}$ & --- & $0 / 1733$ & $0 / 1733$ & $15 / 1692$ & $15 / 1692$ & $20 / 1733$ & $11 / 1733$ & $11 / 1733$ & $12 / 1703$ \\
\hline $\begin{array}{l}\text { A. flavus } \\
\text { NFRI } 1212 \\
\text { D63696.1 }\end{array}$ & 100 & --- & $0 / 1761$ & $15 / 1692$ & $15 / 1692$ & $20 / 1733$ & $11 / 1733$ & $11 / 1733$ & $12 / 1703$ \\
\hline $\begin{array}{l}\text { A. oryzae } \\
\text { ATCC } 1011 \\
\text { D63698.1 }\end{array}$ & 100 & 100 & -- & $15 / 1692$ & $15 / 1692$ & $20 / 1733$ & $11 / 1733$ & $11 / 1733$ & $12 / 1703$ \\
\hline $\begin{array}{l}\text { A. silvaticus } \\
\text { ALI } 234 \\
\text { AF548067.1 }\end{array}$ & 99.11 & 99.11 & 99.11 & --- & $0 / 1692$ & $11 / 1692$ & $20 / 1692$ & $20 / 1692$ & $21 / 1672$ \\
\hline $\begin{array}{l}\text { A. versicolor } \\
\text { UPSC } 2027 \\
\text { AF548068.1 }\end{array}$ & 99.11 & 99.11 & 99.11 & 100 & -- & $11 / 1692$ & $20 / 1692$ & $20 / 1692$ & $21 / 1672$ \\
\hline $\begin{array}{l}\text { A. nidulans } \\
\text { ATCC } 10074 \\
\text { NG_064803.1 }\end{array}$ & 98.85 & 98.85 & 98.85 & 99.35 & 99.35 & -- & $25 / 1733$ & $25 / 1733$ & $26 / 1703$ \\
\hline $\begin{array}{l}\text { A. awamori } \\
\text { IFO4033 } \\
\text { D63695.1 }\end{array}$ & 99.37 & 99.37 & 99.37 & 98.82 & 98.82 & 98.56 & -- & $0 / 1733$ & $1 / 1703$ \\
\hline $\begin{array}{l}\text { A. niger } \\
\text { IFO6341 } \\
\text { D63697.1 }\end{array}$ & 99.37 & 99.37 & 99.37 & 98.82 & 98.82 & 98.56 & 100 & --- & $1 / 1703$ \\
\hline $\begin{array}{l}\text { Isolate } \\
\text { DFSP.J4 }\end{array}$ & 99.3 & 99.3 & 99.3 & 98.74 & 98.74 & 98.47 & 99.94 & 99.94 & --- \\
\hline
\end{tabular}




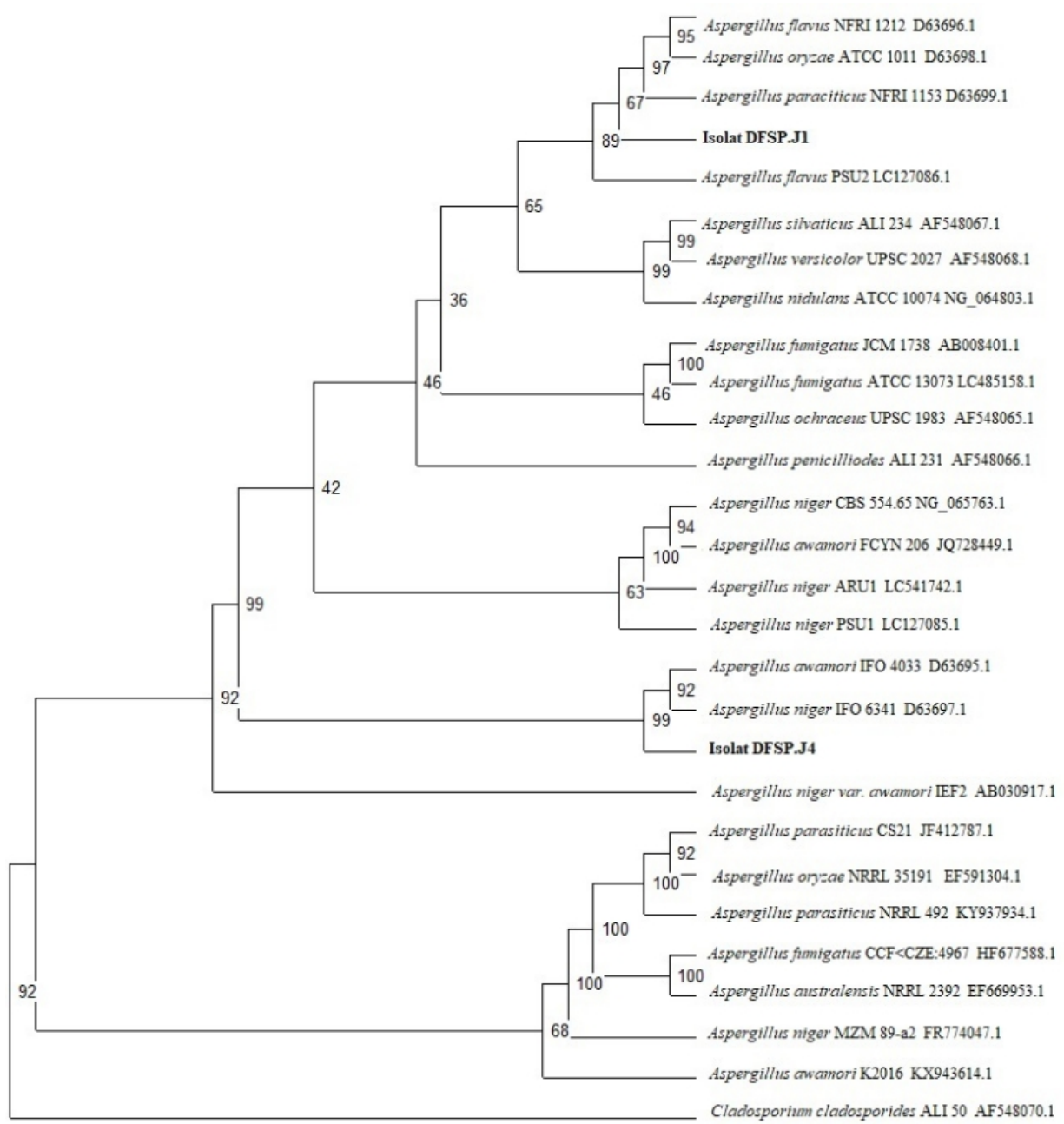

0.01

Figure 5. Phylogeny trees reconstructed based on 18SrRNA gene sequences with the Neighbor Joining algorithm (Saitou and Nei. 1987) which shows the kinship relationship between 27 reference strains belonging to the genus Aspergillus and 2 isolates of biosagoplast degrading fungi. The branching rate indicates the bootstrap value (\%) based on the neighbor-joining analysis with 1000 replications. The arrows indicate the root position of the phylogeny tree using Cladosporium cladosporides ALI50 AF5488070.1 as the outgroup. The scale indicates a substitution rate of 1 per 100 nucleotides in the 18S rRNA gene sequence.

\section{Discussion}

The characteristic of sagoplast were plasticity and hard to tear by hand. Due to the method used is melt intercalation, a phase inverse technique with solvent evaporation after the printing process on the print medium. This method is based on the principle of solution thermodynamics where in the initial conditions it is stable and experiences instability in the process of changing the liquid phase to solid. The process of becoming solid begins with the transfer of the liquid phase to the two-liquid phase (liquid-liquid demixing) so that the polymer phase conditions with high concentrations will form solids (Coniwanti et al., 2014). The use of glycerol as a plasticizer, the higher the concentration does not cause the plastic to be flexible but the bioplastic sago becomes brittle (Zuraida et al., 2012). Making bioplastics has been carried out using various renewable substrates including cassava flour (Wahyuningtyas and Suryanto, 2017); jail flour (Anandito et al., 2012); a mixture of whey and agar
(Ningsih, 2015); plantains, corn cobs and water hyacinth weights (Nahwi, 2016); cassava flour with chitosan (Aripin et al., 2017); rubber cassava (Aryani, 2014). Each bioplastic product has its own character depending on the substrate, concentration and type of catalyst as well as the concentration of the plasticizer and bioplastic characteristics parameters include biodegradability (Wahyuningtyas and Suryanto, 2017).

Isolate DFSP.J1 has conidiophores characters in the shape of a round yellow almost pale color with clear white mycelia. The characters similar with A. flavus, a filamentous and cosmopolitan fungus that can grow in various environmental conditions (Abbas et al., 2009). It is a saprophytic and opportunistic pathogen and thrives in many organic nutrient sources containing monosaccharides and disaccharides (Amaike and Keller, 2011) at temperatures of $12{ }^{\circ} \mathrm{C}$ to $48{ }^{\circ} \mathrm{C}$ with optimal growth temperatures between $28{ }^{\circ} \mathrm{C}$ to $37{ }^{\circ} \mathrm{C}$ with $80 \%$ humidity (Hell and Mutegi, 2011) and (Yu, 2012). Members of the genus Aspergillus have a complex and evolving taxonomy, characterized by the presence of 
conidiophores in the form of colorless, thick-walled, and slightly coarse or perforated vesicles bearing subgloboseshaped vesicles (Rodrigues et al., 2007). The cells are either uniseriate or biseriate or both with conidia round, thin-walled, and slightly rough (Thathana et al., 2017). The characteristics of DFSP.J4 isolate similar with A. niger, macroscopically, white colonies are visible on the gelatinous surface and occasionally a yellow tinge develops which then forms black conidiophores. Slender stalks with small white rounded vesicles that mature into black pigmented spore heads carrying numerous conidia on fialides and metules have been observed. The pronounced round and metulae vesicles can be considered a hallmark of $A$. niger (de Farias et al., 2010). The pigmented conidia that had developed on the conidiophores for 2,5 , and 8 days were resistant to heat (Teertstra et al., 2017). Microscopic morphology of $A$. niger LKO1 shows a large, rounded black conidial head, which becomes diffuse, tends to split into multiple loose columns with age. Conidiophores are smooth-walled, hyaline or turn dark into the vesicles. The head of the conidia is split with fialides that are born on top of brown methula, often septate. Conidia are round with subglobose, black and rough walls (George and Ramteke, 2019).

The isolates have the ability to degrade sagoplasts in minimal nutrient conditions. The ability of microorganism to degrade bioplastics varies depending on the type of microorganism and the treatment of bioplastics when tested for their degradation. A spoon made of bioplastic from cassava flour was degraded $20 \%$ by Coriolus versicolor for 93 days under solid suspense fermentation conditions (Arikan and Bilgen, 2019). The rate of degradation power of bioplastics does not depend on the type of cassava cultivar which has high or lower starch content, but depends on the plasticizer concentration (Udensi et al., 2009). The biodegradability character of bioplastics were determined by looking and weighing before and after the bioplastic specimens are buried in the soil. There is a reduction in the mass of the specimen, indicating a degradation process carried out by microorganisms in the soil (Adhikari et al., 2016). Testing of bioplastics by the method of being buried in the soil shows a degradation process of $80 \%$ by soil microorganisms (Gautam and Kaur, 2013). In other hand, biodegradation of bioplastics materials strongly depends on both, the environment where they are placed and the chemical nature of the material (Adamcová et al., 2017). The rate of degradation is also influenced by the availability of the hydrolase enzyme produced by microorganisms (Danso et al., 2019).

Based on the results of research that has been carried out and various research conducted by other researchers related to the treatment of bioplastics before they are degraded by microorganisms, the isolates of the DFSP.J1 and DFSP.J4 have the advantage of being able to degrade sagoplasts and has the potential to be further developed.

The DFSP.JI isolate was showed that relationship with A. flavus PSU2 LC127086.1 This is because the two isolates have the ability to degrade plastic material. $A$. flavus PSU2 is isolated from rubber wood (Hevea brasiliensis) which is used in the manufacture of toy products. (Oldertrøen, 2016). A.flavus is a saprotrophic and pathogenic fungus. The spread is cosmopolitan (Ramírez-Camejo et al., 2012) with colonies in the form of masses with spores in the form of powder and yellowish green color, many are found in food ingredients containing carbohydrates from cereals, seeds and legumes (Silva et al., 2011). The ability to grow in the sagoplast is due to the presence of nutrients in the form of starch and glycerol in the sagoplast. Isolate DFSP.J4 is related to A. niger IFO 4031 D636697.1 which has a teleomorph form with A. awamori IFO 4033 D63695.1 (Nikkuni et al., 1996). The outgroup used is Cladosporium cladosporioides, because it is a sister group of Aspergillus in one clade even though it is not a member of the Aspergillus group (Wu et al., 2003). In 16S rRNA markers, the percentage identity of microorganism sample is indicated as identical or similar when the value is above to $97.5 \%$ for species level and $95 \%$ for genus level (Stackebrandt and Goebel, 1994).

\section{Acknowledgement}

Our gratitude goes to the Rector of the University and the Chair of the Cenderawasih University Research and Community Service Institute for giving the research team the opportunity to carry out research in the doctoral coaching research scheme at Cenderawasih University from the PNBP fund for the 2020 fiscal year. Thank you also to PT. Genetics Science Indonesia will continue to work together.

\section{References}

Abbas, H. K., Wilkinson, J. R., Zablotowicz, R. M., Accinelli, C., Abel, C. A., Bruns, H. A., and Weaver, M. A. (2009). Ecology of Aspergillus flavus, regulation of aflatoxin production, and management strategies to reduce aflatoxin contamination of corn. Toxin Reviews, 28(2-3), 142-153.

Adamcová, D., Elbl, J., Zloch, J., Vaverková, M. D., Kintl, A., Jư̌ička, D., Hladký, J., and Brtnický, M. (2017). Study on the (bio)degradation process of bioplastic materials under industrial composting conditions. Acta Universitatis Agriculturae et Silviculturae Mendelianae Brunensis, 65(3), 791-798.

Adhikari, D., Mukai, M., Kubota, K., Kai, T., Kaneko, N., Araki, K. S., and Kubo, M. (2016). Degradation of Bioplastics in Soil and Their Degradation Effects on Environmental Microorganisms. Journal of Agricultural Chemistry and Environment, 05(01), 23-34.

Alshehrei, F. (2017). Biodegradation of Synthetic and Natural Plastic by Microorganisms. Journal of Applied \& Environmental Microbiology, 5(1), 8-19.

Amaike, S., and Keller, N. P. (2011). Aspergillus flavus. Annual Review of Phytopathology, 49, 107-133.

Anandito, R. B. K., Nurhartadi, E., and Bukhori, A. (2012). Pengaruh Gliserol terhadap Karakteristik Edible Film Berbahan Dasar Tepung Jali (Coix lacryma-jobi L.). Teknologi Hasil Pertanian, 5(2), 17-23.

Arikan, E. B., and Bilgen, H. D. (2019). Investigation of fungal biodegradation of starch based bioplastic spoon wastes. Journal of Engineering Sciences and Design, 7(2), 294-300.

Aripin, S., Saing, B., Kustiyah, E., Bhayangkara, U., and Raya, J. (2017). Studi Pembuatan Bahan Alternatif Plastik Biodegradable. Jurnal Teknik Mesin (JTM), 06(2), 79-84.

Aryani, R. (2014). Pembuatan Film Biodegradable Menggunakan Pati dari Singkong Karet (Mannihot glazovii). Politeknik Negeri Surabaya, 53(9), 1689-1699. 
Coniwanti, P., Laila, L., and Alfira, M. R. (2014). Pembuatan Film Plastik Biodegredabel Dari Pati Jagung Dengan Penambahan Kitosan Dan Pemplastis Gliserol. Jurnal Teknik Kimia, 20(4), $22-30$.

Danso, D., Chow, J., \& Streita, W. R. (2019). Plastics: Environmental and biotechnological perspectives on microbial degradation. Applied and Environmental Microbiology, 85(19), 1-14.

de Farias, V. L. de, Monteiro, K. X., Rodrigues, S., Fernandes, F. A. N., and Pinto, G. A. S. (2010). Comparison of aspergillus niger spore production on potato dextrose agar (PDA) and crushed corncob medium. Journal of General and Applied Microbiology, 56(5), 399-402.

Gautam, N., and Kaur, I. (2013). Soil burial biodegradation studies of starch grafted polyethylene and identification of Rhizobium meliloti therefrom. Journal of Environmental Chemistry and Ecotoxicology, 5(June), 147-158.

George, M., and Ramteke, P. W. (2019). Morphology, molecular identification and phylogenetic analysis based on internal transcribed spacer (ITS) of the ribosomal nuclear DNA (rDNA) sequence of a pathogenic fungal isolate Aspergillus niger LKO1. Tropical Plant Research, 6(2), 166-170.

Gontia-Mishra, I., Deshmukh, D., Tripathi, N., Bardiya-Bhurat, K., Tantwai, K., and Tiwari, S. (2013). Isolation, morphological and molecular characterization of phytate-hydrolysing fungi by $18 \mathrm{~S}$ rDNA sequence analysis. Brazilian Journal of Microbiology, 44(1), 317-323.

Hell, K., \& Mutegi, C. (2011). Aflatoxin control and prevention strategies in key crops of Sub-Saharan Africa. African Journal of Microbiology Research, 5(5), 459-466.

Maran, J. P., Sivakumar, V., Thirugnanasambandham, K., and Sridhar, R. (2014). Degradation behavior of biocomposites based on cassava starch buried under indoor soil conditions. Carbohydrate Polymers, 101(1), 20-28.

Nahwi, N. F. (2016). Analisis pengaruh penambahan plastisizer gliserol pada karakteristik edible dari pati kulit pisang raja, tongkol jagung dan bonggol enceng gondok. Malang: Universitas Islam Negeri Maulana Malik Ibrahim.

Nikkuni, S., Kosaka, N., Suzuki, C., and Mori, K. (1996). Comparative sequence analysis on the 18s rRNA gene of aspergill us or oryzae, A. sojae, A. flavus, A. parasticus, A. niger, A. wamori and A. tamara. J. Gen. Appl. Microbiol., 42, 181-187.

Ningsih, S. H. (2015). Pengaruh plasticizer gliserol terhadap karakteristik edible film campuran whey dan agar. Makassar: Universitas Hasanuddin.

Oldertrøen, K. (2016). Prevention of Fungal Growth on Rubberwood for Toy Production i Kittiya. Prince of Songkla University.

Ramírez-Camejo, L. A., Zuluaga-Montero, A., Lázaro-Escudero, M., Hernández-Kendall, V., and Bayman, P. (2012). Phylogeography of the cosmopolitan fungus Aspergillus flavus: Is everything everywhere? Fungal Biology, 116(3), 452-463.

Reddy, R. L., Reddy, V. S., and Gupta, G. A. (2008). Study of Bioplastics as green \& sustainable alternative to plastics. International Journal of Emerging Technology and Advanced Engineering, 9001(5), 82-89.
Rodrigues, P., Soares, C., Kozakiewicz, Z., Paterson, R. R. M., and Lima, N. (2007). Identification and characterization of Aspergillus flavus and aflatoxins. Communicating Current Research and Educational Topics and Trends in Applied MIcrobiology. Badajoz, Spain: Méndez-Vilas, A., Ed: FORMATEX, 192(4), 322

Saitou, N., and Nei, M. (1987). The neighbor-joining method: a new method for reconstructing phylogenetic trees. Molecular Biology and Evolution, 4(4), 406-425.

Sihaloho, E. B. (2011). Evaluasi Biodegradabilitas Plastik Berbahan Dasar Campuran Pati dan Polietilen Menggunakan Metode Enzimatik, Konsorsia Mikroba dan Pengomposan. Depok: Universitas Indonesia.

Silva, D. M., Batista, L. R., Rezende, E. F., Fungaro, M. H. P., Sartori, D., and Alves, E. (2011). Identification of fungi of the genus aspergillus section nigri using polyphasic taxonomy. Brazilian Journal of Microbiology, 42(2), 761-773.

Stackebrandt, E., and Goebel, B. M. (1994). Taxonomic note: A place for DNA-DNA reassociation and 16S rRNA sequence analysis in the present species definition in bacteriology. International Journal of Systematic Bacteriology, 44(4), 846-849.

Szumigaj, J., Zakowska, Z., Klimek, L., Rosicka-Kaczmarek, J., and Bartkowiak, A. (2008). Assessment of polylactide foil degradation as a result of filamentous fungi activity. Polish Journal of Environmental Studies, 17(3), 335-341.

Teertstra, W. R., Tegelaar, M., Dijksterhuis, J., Golovina, E. A., Ohm, R. A., \& Wösten, H. A. B. (2017). Maturation of conidia on conidiophores of Aspergillus niger. Fungal Genetics and Biology, 98, 61-70.

Thathana, M. G., Murage, H., Abia, A. L. K., and Pillay, M. (2017) Morphological characterization and determination of aflatoxinproduction potentials of aspergillus flavus isolated from maize and soil in Kenya. Agriculture (Switzerland), 7(10).

Udensi, O., Ikpeme, E. V, Uyoh, E. A., \& Brisibe, E. A. (2009). Evaluation of Starch Biodegradable Plastics Derived from Cassava and Their Rates of Degradation in Soil. Nig J. Biotech, $20,2833$.

Wahyuningtyas, N., and Suryanto, H. (2017). Analysis of Biodegradation of Bioplastics Made of Cassava Starch. Journal of Mechanical Engineering Science and Technology, 1(1), 2431.

Wu, Z., Tsumura, Y., Blomquist, G., and Wang, X. R. (2003). 18S rRNA gene variation among common airborne fungi, and development of specific oligonucleotide probes for the detection of fungal isolates. Applied and Environmental Microbiology, 69(9), 5389-5397.

$\mathrm{Yu}$, J. (2012). Current understanding on aflatoxin biosynthesis and future perspective in reducing aflatoxin contamination. Toxins, 4(11), 1024-1057.

Zuraida, A., Yusliza, Y., Anuar, H., and Mohd Khairul Muhaimin, R. (2012). The effect of water and citric acid on sago starch bioplastics. International Food Research Journal, 19(2), 715-719. 